\title{
Borikenophis portoricensis (Puerto Rican Racer). Distribution.
}

Date of observation: 10 January 2008. Location: Puerto Rico: Cayo Luis Peña. Coordinates: 18.3114, -65.3322. Elevation: 0 $m$. Voucher: image. This is the first record of the species on Culebrita. The snake was moving in forest leaf litter in a coastal forest. The goats present on the island disturb the leaf litter and eat much of the understory vegetation.

Christian Torres-Santana, University of Hawaii, 3190 Maile Way, Honolulu, Hawaii, 96822, USA, cwts@hawaii.edu.

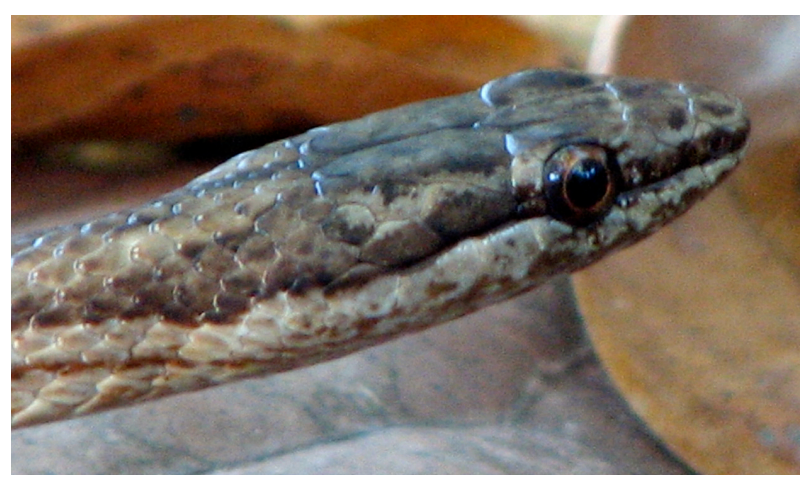

Citation: Torres-Santana C. 2010. Borikenophis portoricensis (Puerto Rican Racer). Distribution. Caribbean Herpetology 13:1.

Published online 24 November 2010 